\title{
Tata Kelola Pembentukan Karakter Siswa di Madrasah Kota Magelang
}

\author{
Sofia Nur ${ }^{* *}$, Purwanto ${ }^{2)}$, Rochmat Budi Santoso ${ }^{3)}$ \\ ${ }^{1,2,3}$ Program Doktor Manajemen Pendidikan Islam, IAIN Surakarta \\ *Email korespondensi: sofianur@gmail.com
}

\begin{abstract}
This study aims to describe governance in the formation of the character of madrasah students in Magelang City in 2021, to describe student responses to the governance of student character building by madrasas in Magelang City in 2021, and to describe the evaluation of governance in character building of madrasah students in Magelang City which including Madrasah Ibtidaiyah, Madrasah Tsanawiyah, and Madrasah Aliyah. This study used descriptive qualitative method. This method is used to describe and explain madrasa management in shaping the character of students in madrasas in the Magelang region. The places chosen to conduct the research were Madrasah Ibtidaiyah, Madrasah Tsanawiyah, Madrasah Aliyah. Madrasah Ibtidaiyah (MI) includes MI Muhammadiyah Terpadu Harapan Magelang City and MI Al Iman City Magelang. Madrasah Tsanawiyah (MTs) include MTsN 1 Magelang City and MTsN 2 Magelang City. Madrasah Aliyah (MA) includes MAN of Magelang City and MA Al Iman of Magelang City. Data collection techniques in this research are using content/document analysis techniques, in-depth interviews, and events/observations. The method used to check the validity of the data is the triangulation method. The results showed that: 1). Governance in shaping the character of madrasa students in Magelang City in 2021 is generally carried out by the madrasah through various habituation and extracurricular activities as well as positive self-development such as reading Asmaul Husna, Tahfidzul Qur'an, Tilawatil Qur'an, Sunnah fasting and others. has gone well; 2). Student responses to the management of student character building by madrasas in Magelang City are generally very good and positive, students carry out various activities implemented by the school enthusiastically and consistently; 3). The evaluation carried out for the formation of student character applied to madrasas in Magelang City was successful and as expected because in general the students had good morals and carried out various positive activities both within the madrasa and outside the madrasa environment.
\end{abstract}

Keywords: governance, character building, madrasa

Saran sitasi: Nur, S., Purwanto., \& Santoso, R. B. (2021). Tata Kelola Pembentukan Karakter Siswa di Madrasah Kota Magelang. Jurnal Ilmiah Ekonomi Islam, 7(02), 881-890. doi:http://dx.doi.org/10.29040/jiei.v7i2.2662

\section{DOI: http://dx.doi.org/10.29040/jiei.v7i2.2662}

\section{PENDAHULUAN}

Pendidikan memegang peran yang sangat penting terhadap eksistensi keberlangsungan manusia. Sejarah mencatat, hampir tidak ada kelompok manusia yang tidak menggunakan pendidikan sebagai alat pembudayaan dan peningkatan kualitas diri (Hujair \& Sanaky, 2003). Sebagai bentuk usaha sadar, pendidikan dibutuhkan dalam pembentukkan karakter seseorang untuk menunjang perannya di masa depan. Dengan demikian, pendidikan merupakan proses budaya yang bertujuan untuk mengangkat harkat dan martabat manusia sepanjang hayat (Haryanti, 2013). Terlebih konsep pendidikan yang menekankan pada nilai-nilai moral dan karakter seseorang. Konsep pendidikan dengan menekankan pada nilai moral memiliki tujuan untuk mewujudkan manusia-manusia yang beradab, yang mampu menempatkan sesuatu sesuai dengan martabat yang sebenarnya, menggunakan cara-cara yang benar untuk mencapai tujuan yang benar, dan memperjuangkan sesuatu untuk mencapai tujuan yang benar (Sarjuni, 2018).

Hingga saat ini pendidikan masih memegang peran yang strategis dan urgen untuk membentuk karakter suatu bangsa, terlebih dengan tugas utamanya yaitu pembentukan karakter peserta didik. Sebagai bagian integral dalam kehidupan manusia, pendidikan memberikan binaan dan bimbingan potensi- potensi pribadi yang berlandaskan nilai-nilai masyarakat dan 


\section{Jurnal Ilmiah Ekonomi Islam, 7(02), 2021, 882}

budaya setempat (Riadi, 2016). Lembaga pendidikan diharapkan memberikan kontribusi besar dalam mewujudkan generasi-generasi yang berkarakter sesuai dengan paradigma yang diusung dalam dunia pendidikan di Indonesia. Paradigma pendidikan karakter dilatarbelakangi oleh kekhawatiran masyarakat juga pemerhati pendidikan akan rendahnya kesadaran beretika, berbudi pekerti, moralitas, semangat kepedulian siswa terhadap diri dan lingkungan sekitar (Maemonah, 2015). Pentingnya pendidikan karakter didorong oleh keprihatinan atas banyaknya perilaku tidak terpuji hampir di semua segi kehidupan. Berbagai kasus moral telah terjadi dan menghiasi berbagai media massa hampir setiap saat, mulai dari kasus korupsi, tindak kekerasan, pelecehan seksual, pornografi, pelacuran, tawuran, penyalahgunaan narkoba, bahkan pembunuhan (Anwar, 2014; Sukirman, Hawi, \& Alimron, 2017). Permasalahan karakter bangsa tersebut dilatarbelakangi oleh realita permasalahan kebangsaan yang berkembang saat ini, seperti: disorientasi dan belum dihayatinya nilai-nilai Pancasila; keterbatasan perangkat kebijakan terpadu dalam mewujudkan nilai-nilai Pancasila; bergesernya nilai etika dalam kehidupan berbangsa dan bernegara; memudarnya kesadaran terhadap nilai- nilai budaya bangsa; ancaman disintegrasi bangsa; dan melemahnya kemandirian bangsa (Kemdiknas, 2011).

Berbagai kasus lain yang seolah membalikkan logika, seakan bangsa ini tidak memiliki cukup peradaban dan moral-etik yang mampu menjadi penangkal bagi perilaku buruk dan destruktif. Nilainilai luhur seperti kejujuran, santun dan keramahan, kebersamaan, dan perilaku religius seolah hilang terkikis oleh "budaya baru" yang hedonistik, materialistik, dan individualistik (Supa'at, 2014). Padahal dalam praktiknya mereka telah mendapatkan pendidikan moral dan pendidikan agama mulai dari jenjang pendidikan dasar sampai pendidikan tinggi. Dengan demikian, sudah selayaknya peserta didik memiliki nilai-nilai yang baik berkarakter. Sebab, pada kenyataannya pendidikan bertujuan untuk mempersiapkan peserta didik menjadi warga negara yang baik. Namun, tujuan pendidikan nasional secara umum belum sepenuhnya tercapai. Hal ini yang menyebabkan mutu lulusan belum sepenuhnya mencerminkan karakter yang diharapkan oleh tujuan nasional tersebut, dimana lulusan saat ini cenderung bersifat pragmatis, sekuler, materialistik, hedonistik, rasionalistik, yaitu manusia yang cerdas secara intelektual dan fisiknya namun kering dari spiritual dan kurang memiliki kecerdasan emosional (Lickona, 2013).

Karakter yang tidak berkembang dengan baik akan berakibat maraknya kenakalan yang terjadi di kalangan pelajar. Munculnya anggapan bahwa pelaksanaan pendidikan karakter memang belum optimal, sebab pendidikan karakter di berbagai sekolah/ madrasah belum bisa dan mampu mengimplementasikannya secara maksimal. Hal ini disebabkan oleh dua hal. Pertama, strategi pembangunan pendidikan selama ini lebih bersifat input oriented, artinya paradigma yang dijalankan pemimpin lembaga pendidikan terlalu bersandar pada asumsi bahwa bilamana semua input pendidikan telah dipenuhi, maka akan menghasilkan output yang bermutu. Kedua, pengelolaan pendidikan selama ini lebih bersifat macro oriented, diatur oleh jajaran birokrasi di tingkat pusat, akibatnya banyak faktor micro atau sekolah/madrasah yang tidak berjalan (Baharuddin \& Makin, 2010).

Merujuk pada tujuan pendidikan nasional, peserta didik seharusnya menjadi mukmin dan mutaqqin yang berakhlak karimah. Namun, terjadinya berbagai pelanggaran dan perilaku menyimpang mengindikasikan bahwa norma dan ajaran yang diperoleh peserta didik di bangku sekolah memungkinkan baru sebatas pengetahuan (kognitif). Bila sekadar pengetahuan tentu belum mampu berkorelasi secara positif dalam bersikap dan bertindak. Artinya kualitas pendidikan dan pengajaran di sekolah atau madrasah belum menyentuh domain yang sesungguhnya menjadi bagian dari tujuan pendidikan, yaitu domain afektif (sikap), dan psikomotorik (keterampilan).

Karakter merupakan suatu implementasi dari tingkah laku dan sikap seseorang, dimana merupakan salah satu pilar penting yang akan menentukan prestasi dan pencapain seseorang. Oleh karena itu, proses pemahaman mengenai pendidikan karakter ini harus mulai ditanamkan sejak dini agar dapat menjadi dasar yang kuat bagi seseorang untuk menghadapi kehidupan di masa mendatang. Pendidikan karakter pada saat ini di implementasikan kedalam semua mata pelajaran. Bukan hanya terintegrasi dalam mata pelajaran $\mathrm{PKn}$, pendidikan agama, dan mata pelajaran lain yang relevan tetapi pendidikan karakter juga terintegrasi ke dalam semua mata pelajaran. Hal ini beretujuan untuk berkembangnya potensi peserta didik agar menjadi 
manusia yang beriman dan bertakwa kepada Tuhan Yang Maha Esa, berakhlak mulia, sehat, berilmu, cakap, kreatif, mandiri, dan menjadi warga negara yang demokratis serta bertanggung jawab.

Berbagai faktor penyebab rendahnya karakter pada generasi muda. Adanya yang disebabkan karena faktor internal dan faktor eksternal. Berbagai jenis baik faktor internal dan eksternal diantaranya yang menyebabkan rusaknya moral pada generasi muda terjadinya: 1) kemajuan teknologi, 2) memudarnya kualitas keimanan, 3) pengaruh lingkungan, 4) hilangnya kejujuran, 5) hilangnya rasa tanggung jawab, 6) tidak berpikir jauh ke depan, 7) rendahnya disiplin. (Fitriyani, 2016). Kendala-kendala itu manjadi bagian yang tidak terlepaskan dari perkembangan remaja dalam mencari jati diri dalam masa menuju pembentukan karakter. Pembentukan jati diri remaja dalam konteks karakter tidak terlepas dengan hasil akhir luaran pendidikan. Pendidikan yang mampu mencetak luaran yang baik tentu harus melalui proses yang bermutu baik. Mutu pendidikan dapat diperoleh melalui pembentukan dan pengembangan karakter yang diinternalisasikan menjadi pribadi yang unggul dan akan menciptakan lulusan yang unggul (Sulhan, 2015). Dengan demikian, untuk menghasilkan mutu lulusan yang unggul dan berkarakter diperlukan manajemen mulai dari perencanaan, pelaksanaan, pengawasan, dan evaluasi.

Pemerintah melalui Kementrian Pendidikan Nasional sejak 2 Mei 2010 telah menggulirkan sebuah terobosan baru menyangkut keharusan dalam mengembangkan pendidikan berbasis karakter. Karakter (watak) merupakan bagian dari kepribadian (personality); di dalam kepribadian terdapat unsur sikap (attitude), sifat (traits), temperamen dan karakter (watak) (Tim Penyusun PPK, 2016). Karakter merupakan struktur batin manusia yang tampak pada tindakan tertentu dan bersifat tetap, baik tindakan itu baik maupun buruk, serta merupakan ciri khas dari pribadi orang yang bersangkutan. Bila temperamen sangat dipengaruhi oleh konstitusi tubuh dan pembawaannya, maka karakter lebih dipengaruhi oleh faktor-faktor lingkungan, seperti pengalaman, pendidikan, intelijensi dan kemauan (Purwanto, 2000).

Menurut Permendikbud. No. 23 Tahun 2017, pengembangan potensi peserta didik sebagaimana dimaksud dalam tujuan pendidikan nasional tersebut secara sistemik-kurikuler diupayakan melalui kegiatan intrakurikuler, kokurikuler, dan ekstrakurikuler. Dalam kaitannya dengan pendidikan di madrasah terdapat lima nilai utama karakter yang menjadi prioritas. Lima nilai karakter tersebut merupakan satu kesatuan utuh yang tidak bisa di pisah- pisahkan, saling mempengaruhi dan saling menentukan dan ditentukan (Tim Penyusun PPK, 2016). Lima nilai karakter pendidikan di madrasah meliputi nilai religius, nasionalis, mandiri, gotong royong, dan integritas. Setiap guru memiliki tanggungjawab untuk bisa menanamkan nilai-nilai tersebut terhadap semua siswa, melalui proses pendidikan di dalam kelas maupun di luar kelas (Anshori, 2017). Selain nilai, terdapat sembilan prinsip dalam pelaksanaan dan pengembangan Gerakan Penguatan Pendidikan Karakter (PPK) di Madrasah, yakni moral universe, holistik, terintegrasi, partisipatif, kearifan lokal, kecakapan, adil dan inklusif, selaras dengan perkembangan peserta didik, dan terukur (Tim Penyusun PPK, 2016:).

Kelima nilai tersebut mulai diterapkan pada sekolah madrasah di berbagai jenjang. Khususnya pada tingkat MI, MTs, dan MA di kota Magelang. Madrasah masih menjadikan karakter sebagai fondasi utama dalam memperbaiki attitude dan meningkatkan kualitas siswa secara intelektual maupun spriritual. Adapun model karakter yang ditunjukkan siswa madrasah di Kota Magelang beragam, namun pada titik tertentu lembaga madrasah menekankan adanya sikap religius, peduli lingkungan, peduli sosial, sopan santun dan cinta tanah air.

Hal tersebut memungkinkan pembentukan karakter siswa madrasah agar lebih berkembang menuju kebiasaan yang baik. Namun, selain siswa sebagai objek pembentukan karakter, dalam hal ini guru diharapkan ikut serta berpartisipasi dalam mendukung pembentukan pengembangan karakter siswa. Oleh sebab itu, integrasi nilai-nilai karakter dalam proses manajemen dapat diterapkan di semua jenjang pendidikan formal, baik pada sekolah umum maupun madrasah. Madrasah menghadapi tantangan yang sama dengan sekolah umum lainnya dalam pembentukan karakter peserta didik. Sebagai lembaga pendidikan formal yang sarat dengan muatan keislaman, madrasah memiliki peluang lebih besar dalam mengintegrasikan nilai-nilai karakter pada seluruh aktivitas pendidikan di madrasah, khususnya pada fungsi manajemen (Muzayanah, 2014).

Hal menarik dari penelitian ini terletak pada objek penelitian. Tidak semua objek yang dikaji telah menerapkan pembentukan karakter dengan optimal. 


\section{Jurnal Ilmiah Ekonomi Islam, 7(02), 2021, 884}

Melainkan terdapat madrasah yang menunjukkan pembentukan karakter yang kurang optimal. Dengan demikian, penelitian ini dapat memberikan gambaran terkait proses pembentukan karakter di madrasah yang sudah baik dan madrasah yang belum menunjukan pembentukan karakter dengan baik. Maka, penelitian ini dapat digunakan sebagai acuan terkait pengelolaan madrasah dalam membentuk karakter siswa.

Manajemen menjadi sesuatu yang sangat vital guna pencapaian tujuan pendidikan karakter secara efektif. Pengelolaan manajemen harus selalu dilakukan secara sistematis dan konsisten melalui langkah-langkah yang disebut dengan fungsi-fungsi manajemen (Salim, 2015). Manajemen pada konteks pendidikan karakter di madrasah pada dasarnya upaya pengondisian peserta didik dan seluruh stakeholder dalam melaksanakan karakter yang luhur. Pada dasarnya beberapa fungsi atau langkah-langkah manajemen pendidikan dapat dikelompokkan menjadi perencanaan, pengorganisasian, pelaksanaan, pengawasan dan pengevaluasian. Dalam mengembangkan karakter siswa, diperlukan pola kelola yang jelas dan konsisten. Selain itu, diperlukan respon siswa untuk melihat keberterimaan dan masukan tata kelola dan strategi evaluasi tata kelola pengembangan karakter. Dengan demikian, akan terbentuk tata kelola yang runut dan konsisten dalam mengembangkan karakter siswa di madrasah.

Berdasarkan deskripsi permasalah pada latar belakang di atas, maka peneliti tertarik untuk melihat tata kelola pengembangan karakter siswa di madrasah yang tersebar di kota Magelang yang mencakup MI (Madrasah Ibtidaiyah), MTs (Madrasah Tsanawiyah), dan MA (Madrasah Aliyah).

\section{KAJIAN TEORI}

\subsection{Pembentukan Karakter Siswa}

Karakter adalah sifat kejiwaan, akhlak atau budi pekerti yang menjadi ciri khas seseorang atau sekelompok orang, karakter juga bisa diartikan sikap, tabiat, akhlak, kepribadian yang stabil sebagai hasil proses konsolidasi secara progresif dan dinamis (Andayani, 2010; Khan, 2010). Karakter merupakan nilai-nilai perilaku manusia yang berhubungan dengan Tuhan Yang Maha Esa, diri sendiri, sesama manusia, lingkungan, dan kebangsaan yang terwujud dalam pikiran, sikap, perasaan, perkataan, dan perbuatan berdasarkan norma-norma agama, budaya dan nilai kebangsaan yang diaktualisasikan dalam kehidupan sehari-sehari menjadi suatu pembiasaan yang melekat (Gunarto, 2004). Dalam terminologi Islam, karakter disamakan dengan khuluq (bentuk tunggal dari akhlaq) akhlak yaitu kondisi batiniyah dalam dan lahiriah (luar) manusia. Kata akhlaq berasal dari kata khalaqa berarti perangai, tabiat, adat istiadat. Menurut pendekatan etimologi kata akhlaq berasal dari basaha arab yang bentuk mufradnya adalah khuluqun diartikan budi pekerti, perangai, tingkah laku atau tabiat. Kalimat ini mengandung segi-segi persesuaian dengan perkataan khalqun yang berarti kejadian, serta erat hubungannya dengan khaliq yang artinya pencipta, dan makhluk yang artinya yang diciptakan (Ramayulis, 2012).

Menurut (Mahmud, 2004) akhlak adalah istilah bagi sesuatu sifat yang tertanam kuat dalam diri yang darinya keluar perbuatan- perbuatan dengan mudah, ringan, tanpa perlu berpikir dan merenung. Akhlak dalah sifat manusia dalam bergaul dengan sesamanya ada yang terpuji, ada yang tercela. khuluk mencakup kondisi lahir dan batin manusia, baik teraktualisasi atau tidak semuanya masuk dalam kategori karakter. Dengan demikian, khuluqmemiliki makna ekuivalen dengan karakter.

Dalam bukunya, Thomas Lickona menyatakan bahwa pengertian pendidikan karakter adalah suatu usaha yang disengaja untuk membantu seseorang sehingga ia dapat memahami, memperhatikan, dan melakukan nilai-nilai etika yang inti. Menurut Lickona, karakter berkaitan dengan konsep moral (moral knonwing), sikap moral (moral felling), dan perilaku moral (moral behavior). Berdasarkan ketiga komponen ini dapat dinyatakan bahwa karakter yang baik didukung oleh pengetahuan tentang kebaikan, keinginan untuk berbuat baik, dan melakukan perbuatan kebaikan. Berdasarkan ketiga komponen ini dapat dinyatakan bahwa karakter yang baik didukung oleh pengetahuan tentang kebaikan, keinginan untuk berbuat baik, dan melakukan perbuatan kebaikan (Lickona, 2015). Thomas Lickona menyebutkan sepuluh karakter esensial dan utama yang harus ditanamkan kepada peserta didik baik di sekolah, di rumah, dan di komunitas/masyarakat meliputi: kebijaksanaan, keadilan, ketabahan, kendali diri, kasih, sikap positif, kerja keras, integritas, rasa syukur, kerendahan hati.

Nilai pendidikan karakter yang dirumuskan oleh para pakar pendidikan melalui Kementerian Pendidikan Nasional berjumlah delapan belas poin. Nilai-nilai tersebut tercantum di dalam sistem 
pendidikan karakter yang bertujuan untuk mengembangkan potensi peserta didik agar menjadi manusia yang beriman dan bertakwa kepada Tuhan YME, peduli sosial, mandiri, bertanggung jawab, bekerja keras, komunikatif dan lai-lain. Kementerian Pendidikan Nasional telah menyiapkan sebanyak 18 butir pendidikan karakter yang dituangkan dalam pendidikan formal. Pendidikan karakter dimaksud meliputi: (1) religius; (2) jujur; (3) toleransi; (4) disiplin; (5) kerja keras; (6) kreatif; (7) mandiri; (8) demokratis; (9) rasa ingin tahu; (10) semangat kebangsaan; (11) cinta tanah air; (12) menghargai prestasi; (13) bersahabat/komunikatif; (14) cinta damai; (15) gemar membaca; (16) peduli lingkungan; (17) peduli sosial dan; (18) tanggung jawab. Karakterkarakter yang telah disiapkan oleh Kementerian Pendidikan Nasional tertuang dalam kurikulum 2013.

Tujuan pendidikan nasional tersebut berusaha membentuk setiap warga negara untuk memiliki watak yang baik. Namun, pada kenyataannya masyarakat kini sering menyimpang dari watak-watak yang dianggap luhur. Jika demikian, maka pendidikan yang diterapkan dapat dikatakan telah gagal membangun karakter yang baik sesuai tujuan pendidikan nasional. Kosim (2011) menjelaskan bahwa problematika karakter yang muncul di masyarakat menunjukkan pendidikan karakter yang diterapkan di sekolah melalui pengembangan pendidikan agama dan pendidikan kewarganegaraan telah gagal membentuk peserta didik yang berkarakter. Baik pendidikan agama dan kewarganegaraan hanya pada tahap pengenalan norma atau nilai-nilai dan belum pada tahap internalisasi dan praktik nyata dalam kehidupan sehari-hari.

Menurut Naufary (2015) tujuan pendidikan karakter yang diterapkan di sekolah ada tiga yaitu: mengembangkan potensi dasar agar berhati baik, berpikiran baik, dan berperilaku baik, memperkuat dan membangun perilaku bangsa yang multikultur, dan meningkatkan peradaban bangsa yang kompetitif dalam pergaulan dunia. Tujuan-tujuan pendidikan karakter tersebut dapat dicapai apabila seluruh komponen sekolah dan masyarakat umum mampu bekerjasama untuk mencapai tujuan tersebut dengan konsisten. Tercapainya tujuan pendidikan karakter pada peserta didik merupakan hal utama dalam pelaksanaan pendidikan karakter di lembaga pendidikan khususnya sekolah.

Beberapa metode yang dapat digunakan dalam pembinaan karakter dan akhlak anak didik menurut
(Nata, 2011) meliputi: (1) metode pembiasaan; (2) metode keteladanan; (3) memperhatikan faktor kejiwaan yang akan dibina. Di sekolah/madrasah guru beserta stakeholder sangat berpengaruh terhadap pembentukan karakter siswa, karena segala sesuatu yang dilakukan oleh guru mampu mempengaruhi karakter peserta didik. Karakter terbentuk dari tiga macam bagian yang saling berkaitan yakni pengetahuan moral, perasaan moral, dan perilaku moral. Menunjukan keteladanan adalah metode yang wajib dilakukan dalam membentuk karakter anak. Guru harus menunjukkan perilaku yang sesuai dengan nasihat atau atribut karakter yang ingin dibentuk dalam diri anak (Sani \& Kadri, 2016).

Menurut Permendikbud. No. 23 Tahun 2017, pengembangan potensi peserta didik sebagaimana dimaksud dalam tujuan pendidikan nasional tersebut secara sistemik-kurikuler diupayakan melalui kegiatan intrakurikuler, kokurikuler, dan ekstrakurikuler. Kegiatan intrakurikuler sebagaimana dimaksud pada ayat (1) merupakan kegiatan yang dilaksanakan untuk pemenuhan kurikulum sesuai dengan ketentuan peraturan perundang-undangan. Kegiatan kokurikuler sebagaimana dimaksud pada ayat (1) merupakan kegiatan yang dilaksanakan untuk penguatan atau pendalaman kompetensi dasar atau indikator pada mata pelajaran/bidang sesuai dengan kurikulum. Kegiatan kokurikuler sebagaimana dimaksud pada ayat (3) meliputi kegiatan pengayaan mata pelajaran, kegiatan ilmiah, pembimbingan seni dan budaya, dan/atau bentuk kegiatan lain untuk penguatan karakter peserta didik. Kegiatan ekstrakurikuler sebagaimana dimaksud pada ayat (1) merupakan kegiatan di bawah bimbingan dan pengawasan sekolah yang bertujuan untuk mengembangkan potensi, bakat, minat, kemampuan, kepribadian, kerjasama, dan kemandirian Peserta Didik secara optimal untuk mendukung pencapaian tujuan pendidikan.

Implementasi pengembangan karakter dalam lingkungan sekolah bersifat terstruktur dan terencana. Untuk itu, diperlukan pengelolaan pengembangan karakter yang baik. Implementasi penguatan tata kelola pengembangan karakter di sekolah dapat menggunakan beberapa metode. Pada pembahasan sebelumnya telah dibahas mengenai metode-metode pembentukan karakter yang meliputi meliputi (1) metode pembiasaan; (2) metode keteladanan; (3) memperhatikan faktor kejiwaan yang akan dibina. Ketiga metode tersebut dapat mendukung dalam penguatan tata kelola pengembangan karakter melalui 


\section{Jurnal Ilmiah Ekonomi Islam, 7(02), 2021, 886}

kegiatan intrakurikuler, kokurikuler, dan ekstrakurikuler. Dalam menerapkan tata kelola pengembangan karakter, sebelumnya masing-masing anggota organisasi sekolah sejak awal dengan cara masing-masing mendefinisikan, memahami, serta menyampaikan visi, misi, dan tujuan sekolah tersebut. Hal tersebut dilakukan sebagai bentuk pengelolaan pengembangan karakter melalui hal-hal yang mendasar seperti visi, misi, dan tujuan sekolah, yang kemudian direpresentasikan ke dalam perilaku dan gaya hidup anggota organisasi sekolah sebagai gerakan bersama dalam mewujudkan siswa yang berkarakter. Tata kelola pengembangan karakter di sekolah bukan sebuah peran struktural akan tetapi lebih ditinjau sebagai sebuah proses bersama dalam organisasi sekolah tersebut, sehingga praktik tata kelola pengembangan karakter tidak hanya diajarkan atau ditujukan kepada peserta didik saja untuk mengenal hal baik bagi dirinya tetapi bagi segenap organisasi sekolah. Pencapaian pembentukan karakter di sekolah/madrasah diperlukan berbagai pihak untuk mewujudkannya. Keterlibatan berbagai pihak tersebut memerlukan tata kelola atau manajemen yang baik untuk mengatur semua pihak menuju pengembangan karakter.

Hoover (2002) menyatakan bahwa keberhasilan dalam proses pembentukan karakter pada suatu lembaga pendidikan, tidak ditentukan oleh kekuatan proses pembelajaran, tetapi ditentukan oleh kekuatan pengelolaannya, yang mengandung arti bahwa karakter peserta didik yang berkualitas sangat bergantung pada mutu sekolah. Sebab, proses pembentukan karakter harus diintegrasikan ke dalam berbagai bentuk kegiatan sekolah. Oleh karena itu, sebuah tata kelola atau manajemen pengembangan karakter harus disusun dengan baik agar tujuan pembentukan karakter siswa tercapai. Ketika kriteria standar tata kelola pengembangan karakter sudah diketahui, maka dapat dibuat desain tata kelola pendidikan karakter di sekolah. Wiyani (2012) menjelaskan bahwa dalam desain manajamen pendidikan karakter di madrasah terdiri dari lima komponen, yaitu guru, kurikulum, pembiayaan, kepemimpinan madrasah, disiplin, dan rasa persaudaraan.

Hasil keluaran dari tata kelola pengembangan karakter adalah karakter siswa itu sendiri. Karena karakter termasuk dalam ranah afektif penilaiannya dilakukan dengan cara mengamati perilaku siswa selama dalam dan luar pembelajaran maupun di area sekolah. Sekolah sebagai bentuk organisasi memiliki pengaruh yang besar dalam pembentukan karakter melalui fungsi-fungsi manajemen atau tata kelola pengembangan karakter tersebut.

\subsection{Manajemen Madrasah}

Secara etimologi manajemen diambil dari bahasa Inggris "manage" yang artinya mengemudikan, mengurus dan memerintah (Tantowi, 1983). Kata manage berasal dari bahasa Italia, maneggio, yang diadopsi dari bahasa Latin managiare, yang berasal dari kata manus, yang artinya tangan (Samsudin, 2006). Dalam arti yang luas manajemen berkaitan dengan menetapkan sebuah arah, maksud dan tujuan, kemudian merencanakan bagaimana mencapai tujuan tersebut denganmengatur sumber daya yang tersedia seefektif mungkin, sehingga dapat mengendalikanbagaimana prosesnya berlangsung yang berakhir pada penetapan dan peningkatan standar (Everard, Morris, \& Wilson, 2004). Schein (2008) memberi definisi manajemen sebagai profesi. Menurutnya manajemen merupakan suatu profesi yang dituntut bekerja profesional, karakteristiknya adalah para profesional membuat keputusan berdsarkan prinsip-prinsip umum, para profesional mendapatkan status mereka karena mereka mencapai standar prestasi kerja tertentu, dan para profesional harus ditentukan suatu kode etik yang kuat.

Madrasah berasal dari akar kata darrasa, yaitu belajar, sedangkan madrasah berarti tempat belajar atau sekolah formal. Madrasah menurut orang awam adalah lembaga pendidikan tingkat dasar dan menengah yang mengajarkan agama Islam saja, perpaduan antara ilmu agama Islam dan ilmu umum, maupun ilmu berbasis ajaran Islam (Nata, 2011).

Pendidikan adalah suatu proses keinsyafan atau penyadaran diri dalam merealisasikan dirinya dan mengembangkan semua potensinya (Kneller, 1996). Manajemen pendidikan madrasah adalah sebagai keseluruhan proses aktivitas bersama didalam bidang pendidikan madrasah dengan memanfaatkan semua fasilitas yang ada baik bersifat personal maupun komunal atau kelompok guna mencapai tujuan pendidikan agama Islam. Pada dasarnya manejemen pendidikan adalah sebuah proses kerja sama dalam rangka usaha mencapai tujuan pendidikan yang telah ditetapkan, sehingga peranannya menjadi sangat penting dalam pengelolaan program pendidikan. Kerja sama yang baik antar personel dalam lembaga pendidikan dapat memudahkan pelaksanaan kegiatan pendidikan. Melalui manajemen pendidikan, 


\section{Jurnal Ilmiah Ekonomi Islam, 7(02), 2021, 887}

seseorang ditempatkan sesuai dengan profesi dan bidang keahliannya. Kesuksesan lembaga pendidikan dalam menempatkan seseorang dengan sesuai dapat dinilai melalui manajemennya.

Manajemen pendidikan karakter yang efektif jika terintegrasi dalam manajemen sekolah, khususnya manajemen berbasis sekolah. Dengan kata lain, pendidikan karakter di sekolah juga terkait dengan manajemen atau pengelolaan sekolah. Muslich (2013) menyatakan bahwa karakter merupakan kualitas moral dan mental seseorang yang pembentukannya dipengaruhi oleh faktor bawaan (fitrah, nature) dan lingkungan (sosialisasi pendidikan, nurture). Potensi karakter yang baik dimiliki manusia sebelum dilahirkan, tetapi potensi-potensi tersebut harus dibina melalui sosialisi dan pendidikan sejak usia dini.

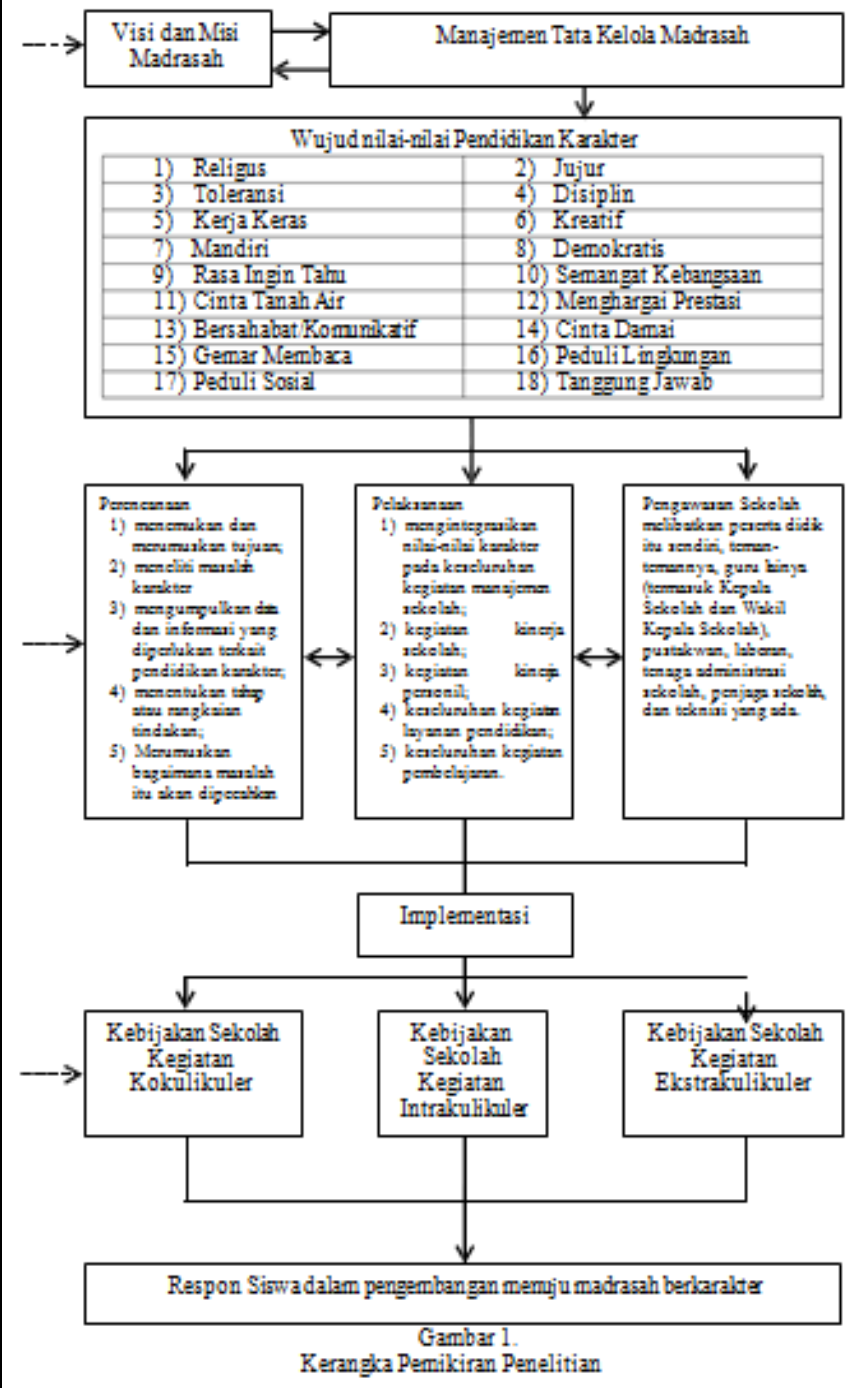

\section{METODOLOGI PENELITIAN}

Penelitian ini menggunakan metode deskriptif kualitatif. Penelitian kualitatif bertujuan untuk memperoleh wawasan terkait konstruksi realitas yang terjadi untuk ditafsirkan (Cropley, 2019). Metode diskripstif kualitatif merupakan metode yang berusaha menggambarkan dan menjelaskan objek dengan sebenarnya dan apa adanya. Metode tersebut digunakan untuk mendeskripsikan dan menjelaskan manajemen madrasah dalam membentuk karakter siswa di madrasah wilayah Magelang. Penelitian ini menggunakan metode penelitian kualitatif karena penelitian dilakukan untuk memahami keunikan. Hal menarik dari penelitian ini terletak pada objek penelitian. Tidak semua objek yang dikaji telah menerapkan pembentukan karakter dengan optimal. Melainkan terdapat madrasah yang menunjukkan pembentukan karakter yang kurang optimal. Dengan demikian, penelitian ini dapat memberikan gambaran terkait proses pembentukan karakter di madrasah yang sudah baik dan madrasah yang belum menunjukan pembentukan karakter dengan baik. Fokus penelitian ini pada tata kelola madrasah dalam pembentukan karakter siswa-siswanya dengan berbagai kegiatan pendukung dalam penanaman pendidikan karakter untuk membentuk generasi yang sesuai visi misi madrasah. Tempat yang dipilih untuk melakukan penelitian yaitu di Madrasah Ibtidaiyah, Madrasah Tsanawiyah, Madrasah Aliyah. Madrasah Ibtidaiyah (MI) meliputi MI Muhammadiyah Terpadu Harapan Kota Magelang dan MI Al Iman Kota Magelang. Madrasah Tsanawiyah (MTs) meliputi MTsN 1 Kota Magelang dan MTsN 2 Kota Magelang. Madrasah Aliyah (MA) meliputi MAN Kota Magelang dan MA Al Iman Kota Magelang.

Teknik pengumpulan data dalam penelitian ini ialah dengan menggunakan teknik analisis isi/dokumen, wawancara mendalam (in depth interview), dan peristiwa/observasi. Metode yang digunakan untuk memeriksa keabsahan data adalah dengan triangulasi method yaitu dengan memanfaatkan berbagai metode sebagai pertimbangan. Triangulasi ini dilakukan dengan jalan membandingkan dan mengecek informasi atau data yang diperoleh dari dokumentasi dengan hasil pengamatan dan interview (Moleong, 2013). Tahaptahap dalam menganalisis data pada penelitian ini ialah: 1). mengidentifikasi kegiatan-kegiatan pendukung pendidikan karakter di madrasah mulai dari MI, MTs, dan MA; 2). mengetahui pola kegiatan yang mampu membentuk karakter siswa melalui kegiatan di sekolah yang bersifat intrakulikuler, kokolikuler dan ekstrakulikuler; 3). melakukan pengumpulan data dari berbagai bentuk kegiatan selanjutnya mengelompokkan pola-pola 


\section{Jurnal Ilmiah Ekonomi Islam, 7(02), 2021, 888}

komponen pengembang karakter dalam kegiatan dalam tata manajemen madrasah; 4). menganalisis respon siswa dalam berbagai bentuk kegiatan pendukung managemen pendidikan karakter; 5). langkah selanjutnya melakukan analisis pengumpulan data dari bentuk evaluasi managemen karakter. 6). terakhir memadukan antara data pendidikan karakter dengan tata kelola manajemen dan evaluasi pendidikan karakter untuk dilakukan intepretasi dalam menarik kesimpulan.

\section{HASIL PENELITIAN}

4.1. Tata kelola dalam pembentukan karakter siswa madrasah di Kota Magelang tahun 2021

Tata kelola pembentukan karakter di MI Al-Iman Kota Magelang dilakukan dengan menerapkan pendidikan karakter kepada para siswa melalui berbagai kegiatan pembiasaan dan ekstrakurikuler serta pengembangan diri. Kegiatan pembiasaan di antaranya membaca asmaul husna, tahfidzul qur'an surah-surah terpilih, dan shalat Dhuha sebelum pembelajaran. Sementara kegiatan ekstrakurikuler dilaksanakan melalui kegiatan pramuka, tilawatil Qur'an, memanah, marching band, dan berenang. Sementara dalam kegiatan pembelajaran, guru harus mengintegrasikan pendidikan karakter melalui ayatayat Al-Qur'an yang sesuai dengan kompetensi yang disampaikan. Dalam rangka memantau memantau perkembangan karakter siswa, MI Al-Iman juga bekerja sama dengan orang tua melalui buku penghubung. Buku itu berisi tentang aktivitas siswa yang berkesinambungan dengan kegiatan- kegiatan penanaman karakter siswa di madrasah. Dengan demikian, sikap dan perilaku siswa dapat dipantau, baik di rumah maupun di sekolah. Itulah beberapa Langkah yang lakukan MI Al-Iman dalam rangka menguatkan karakter para siswanya di madrasah.

Tata kelola pembentukan karakter di tingkat Madrasah Tsanawiah dalam kaitannya tentang pendidikan karakter di Kota Magelang diantaranya dengan cara membiasakan siswa menjalankan salat fardu, menertibkan siswa untuk membaca al-Qur'an, membiasakan berzikir, dan berdoa setelah salat, membiasakan siswa berinfak dan sedekah, membiasakan membaca Asmaul Husna, dan Selawat, pembiasaan berbaris sebelum masuk kelas, sampai pada pembiasaan literasi sebelum KBM dimulai. Hal tersebut memungkinkan pembentukan karakter siswa madrasah agar lebih berkembang menuju kebiasaan yang baik. Namun, selain siswa sebagai objek pembentukan karakter, dalam hal ini guru diharapkan ikut serta berpartisipasi dalam mendukung pembentukan pengembangan karakter siswa. Salah satunya adalah menjadi contoh. Guru harus bisa menjadi contoh bagi siswa, menjadi apresiator, mampu mengajarkan nilai moral pada setiap pelajaran, menunjukkan sikap jujur dan terbuka pada kesalahan, mengajarkan sopan santun pada siswa dan memberi kesempatan siswa belajar untuk menjadi pemimpin.

Tata kelola pembentukan karakter di tingkat Madrasah Aliyah dalam kaitannya tentang pendidikan karakter di Kota Magelang secara umum hampir sama dengan yang diterapkan pada Madrasah Tsanawiyah, hanya saja ada beberapa penambahan pendidikan karakter yang diterapkan yaitu dalam hal kaitannya dengan al-Qur'an tidak hanya sekedar membaca, namun pihak sekolah mewajiban siswa menyelesaikan hafalan al-Qur'an bagi setiap tingkat (kelas) siswa Madrasah Aliyah. Selain membaca dan menghafal alQur'an pihak madrasah membiasakan untuk puasa senin kamis bagi siswa termasuk bagi gurunya. Puasa senin kamis tersebut dalam rangka membentuk karakter para siswa Madrasah Aliyah dalam mengendalikan hawa nafsunya di tengah-tengah mereka menginjak remaja yang seringkali terjadi pubersitas, sehingga hawa nafsu dapat terkendali yang tentu saja berpengaruh terhadap perilaku para siswa dalam sehari-hari yang terkontrol dalam pergaulan.

4.2. Respon siswa terhadap tata kelola pembentukan karakter siswa oleh madrasah di Kota Magelang tahun 2021

Respon siswa terhadap tata kelola pembentukan karakter siswa oleh madrasah di Kota Magelang secara umum sangat baik dan positif, siswa melaksanakan berbagai kegiatan pembiasaan dan ekstrakurikuler serta pengembangan diri yang diterapkan madrasah dengan penuh antusias dan konsisten. Hal tersebut dibuktikan dengan para siswa mengikuti mayoritas program pembentukan karakter yang telah diprogramkan dari pihak madrasah dan melaporkan kegiatan tersebut kepada para pembina kegiatan masing-masing yang telah ditugaskan oleh kepala sekolah seperti menjalankan salat fardu, menertibkan siswa untuk membaca al-Qur'an, membiasakan berzikir, dan berdoa setelah salat, membiasakan siswa berinfak dan sedekah, membiasakan membaca Asmaul Husna, dan Selawat, pembiasaan berbaris sebelum masuk kelas, sampai pada pembiasaan literasi sebelum KBM dimulai. 


\section{Jurnal Ilmiah Ekonomi Islam, 7(02), 2021, 889}

Respon yang baik dan positif tersebut tentu saja karena adanya dukungan pula dari berbagai pihak terutama para wali murid yang senantiasa kita libatkan dalam mengontrol dan ikut memantau anak-anak mereka terutama ketika di rumah atau di luar lingkungan madrasah, serta peran aktif masyarakat sekitar lingkungan madrasah yang juga mendukung program-program pembentukan karakter yang selama ini telah diterapkan pihak madrasah.

4.3. Evaluasi tata kelola dalam pembentukan karakter siswa madrasah di Kota Magelang yang meliputi Madrasa Ibtidaiyah, Madrasah Tsanawiyah, dan Madrasah Aliyah

Evaluasi tata kelola dalam pembentukan karakter siswa madrasah di Kota Magelang yang meliputi Madrasa Ibtidaiyah, Madrasah Tsanawiyah, dan Madrasah Aliyah dilakukan pihak madrasah melalui pemantauan harian, mingguan, maupun bulanan terhadap para siswa dengan melaksanakan kegiatan kontrol (ceklist) kegiatan dari masing-masing siswa oleh para pembina kegiatan. Setelah dilakukan evaluasi dengan memadukan antara data pendidikan karakter dengan tata kelola manajemen dan evaluasi pendidikan karakter untuk dilakukan intepretasi dalam menarik kesimpulan, menunjukkan bahwa pembentukan karakter siswa di Kota Magelang sudah menunjukkan hasil yang diharapkan untuk sebagian besar madrasah, namun sebagian kecil masih perlu dibina dan dievaluasi untuk menanamkan karakter tersebut. Seperti karakter siswa MI Muhammadiyah yang masih perlu dibina dan ditingkatkan kembali, sebab sebagian siswa masih melakukan pelanggaran kedisiplinan berupa malas belajar, sering terlambat, tidak menghargai guru, tidak sopan santun dan kurangnya kepedulian terhadap lingkungan. Hal tersebut memungkinkan pembentukan karakter siswa madrasah agar lebih berkembang menuju kebiasaan yang baik. Namun secara umum dari hasil evaluasi yang dilakukan pembentukan karakter siswa yang diterapkan pada madrasah di Kota Magelang sudah berhasil dan sesuai yang diharapkan karena para siswa pada madrasah di Kota Magelang memiliki akhlakul karimah dan melakukan berbagai kegiatan positif baik saat di lingkungan madrasah maupun di luar lingkungan madrasah.

\section{KESIMPULAN}

Berdasarkan hasil penelitian, maka dapat disimpulkan bahwa: 1). tata kelola dalam pembentukan karakter siswa madrasah di Kota
Magelang tahun 2021 secara umum dilakukan pihak madrasah melalui berbagai kegiatan pembiasaan dan ekstrakurikuler serta pengembangan diri yang sifatnya positif seperti membaca asmaul husna, tahfidzul qur'an, tilawatil Qur'an, puasa sunah dan lain-lain sudah berjalan dengan baik; 2). Respon siswa terhadap tata kelola pembentukan karakter siswa oleh madrasah di Kota Magelang secara umum sangat baik dan positif, siswa melaksanakan berbagai kegiatan yang diterapkan sekolah dengan penuh antusias dan konsisten; 3). evaluasi yang dilakukan pembentukan karakter siswa yang diterapkan pada madrasah di Kota Magelang sudah berhasil dan sesuai yang diharapkan karena secara umum para siswa memiliki akhlakul karimah dan melakukan berbagai kegiatan positif baik saat di lingkungan madrasah maupun di luar lingkungan madrasah.

\section{DAFTAR PUSTAKA}

Andayani, D. (2010). Pedidikan Karakter dalam Perspektif Islam. Bandung: Insan Cita Utama.

Anwar, S. (2014). Pendidikan Karakter di Madrasah Ibtidaiyah Modern Sahid, Bogor, Jawa Barat. EDUKASI, 12(3), 323-337.

Baharuddin, \& Makin, M. (2010). Manajemen Pendidikan Islam, Transformasi Menuju Sekolah/Madrasah Unggul. Malang: UIN-Maliki Press.

Cropley, A. (2019). Introduction to Qualitative Research Methods. Riga, Latvia: Zinātne. https://doi.org/10.13140/RG.2.1.3095.6888

Everard, K. B., Morris, G., \& Wilson, I. (2004). Effective school management. Effective School Management (4th ed.). London: SAGE Publication Ltd. https://doi.org/10.4135/9781446211427

Gunarto. (2004). Konsep Kurikulum di Indonesia. Bandung: Rosda Karya.

Haryanti, N. (2013). Implementasi Pemikiran KH Hasyim Asy'ari tentang Etika Pendidik. Episteme, 8(2), 439-450.

Hoover, E. A. (2000). Getting Along in Family Business The Relationship Intelligence Handbook. Jakarta: PT. Raja Gravindo Persada.

Hujair, A. ., \& Sanaky. (2003). Paradigma Pendidikan Islam Membangun Masyarakat Madani Indonesia. Yogyakarta: Safiria Insania Press.

Kemdiknas. (2011). Panduan Pelaksanaan Pendidikan Karakter. Jakarta: Kemdiknas. 


\section{Jurnal Ilmiah Ekonomi Islam, 7(02), 2021, 890}

Khan, Y. (2010). Pendidikan Karakter Berbasis Potensi Diri: Mendongkrak Kualitas Pendidikan. Yogyakarta: Pelangi Publishing.

Kneller, G. F. (1996). Logic and language of Education. New York: Jhon Willey and Inc.

Kosim, M. (2011). Urgensi pendidikan karakter. KARSA: Journal of Social and Islamic Culture, 84-92.

Lahir, S., Ma'ruf, M. H., \& Tho'in, M. (2017). Peningkatan Prestasi Belajar Melalui Model Pembelajaran Yang Tepat Pada Sekolah Dasar Sampai Perguruan Tinggi. Jurnal Ilmiah Edunomika, 1(01).

Lickona, T. (2013). Mendidik untuk Membentuk Karakter: Bagaimana Sekolah dapat Memberikan Pendidikan tentang Sikap Hormat dan Tanggung Jawab. Bandung: Nusamedia.

Lickona, T. (2015). Character Matters. Jakarta: PT Bumi Aksara.

Maemonah. (2015). Implementasi Pendidikan Karakter di Madrasah/Sekolah. Al- Bidayah: Jurnal Pendidikan Dasar Islam, 7(1), 41-50.

Mahmud, A. A. H. (2004). Akhlak Mulia. Jakarta: Gema Insani Pres.

Moleong, Lexy J. (2013). Metodologi Penelitian Kualitatif. Bandung: Remaja Rosdakarya.

Muslich, M. (2013). Pendidikan Karakter Menjawab Tantangan Krisis Multidimensional. Jakarta: Kencana.

Muzayanah, U. (2014). Manajemen Madrasah sebagai Media Strategis Pendidikan Karakter. Analisa, 21(02), 279-289.

Nata, A. (2011). Akhlak Tasawuf. Jakarta: PT Raja Grafindo Persada.

Purwanto, M. N. (2000). Psikologi Pendidikan. Bandung: PT. Remaja Rosdakarya.

Ramayulis. (2012). Ilmu Pendidikan Islam. Jakarta: Kalam Mulia Group.

Riadi, A. (2016). Pendidikan Karakter di Madrasah/Sekolah. Ittihad Jurnal Kopertais Wilayah XI Kalimantan, 14(26), 1-10.
Salim, A. (2015). Manajemen Pendidikan Karakter di Madrasah (Sebuah Konsep dan Penerapannya). TARBAWI, 1(02), 1-16.

Samsudin. (2006). Manajemen Sumber Daya Manusia. Bandung: Pustaka Setia.

Sani, R. A., \& Kadri, M. (2016). Pendidikan Karakter Mengembangkan Karakter Anak yang Islami. Jakarta: Bumi Aksara.

Sarjuni. (2018). Konsep Ilmu dalam Islam dan Implikasinya dalam Praktik Pendidikan. Al Fikri: Jurnal Studi Dan Penelitian Pendidikan Islam, 1(2), 47-57.

Schein, E. H. (2008). Organizational Culture and Leadership. San Fransisco: Jossey-Bass.

Sukirman, Hawi, A., \& Alimron. (2017). Pelaksanaan Pendidikan Karakter di Madrasah Aliyah Negeri 2 Palembang. Tadrib, 3(2).

Sulhan, A. (2015a). Manajemen Pendidikan Karakter dalam Mewujudkan Mutu Lulusan. UIN Maulana Malik Ibrahim Malang.

Sulhan, A. (2015b). Manajemen Pendidikan Karakter dalam Mewujudkan Mutu Lulusan (Studi Multikasus di MA Dakwah Islamiyah Putri Kediri Lombok Barat dan SMA Negeri 2 Mataram). UIN Maulana Malik Ibrahim.

Supa'at. (2014). Model Kebijakan Pendidikan Karakter di Madrasah. Jurnal Pendidikan Islam, IIII (1), 203-225. https://doi.org/10.14421/jpi.2014.31.203-225

Tantowi, J. (1983). Unsur-Unsur Manajemen dalam Al-Quran. Jakarta: Pustaka Al- Husna.

Tim Penyusun PPK. (2016). Panduan Penilaian Penguatan Pendidikan Karakter Tingkat Sekolah Dasar dan Sekolah Menengah Pertama. Jakarta: Kementerian Pendidikan dan Kebudayaan Republik Indonesia.

Wiyani, N. A. (2012). Desain Manajemen Pendidikan Karakter di Madrasah. INSANIA: Jurnal Pemikiran Alternatif Kependidikan, 17(1). 